СЕРЕДНЬОВІЧНА ФІЛОСОФІЯ

\title{
Rostislav Tkachenko
}

\section{A THOMISTIC UNTRANSLATABLE: A CONCEPTUAL ANALYSIS OF AQUINAS' DOCTRINE OF TRANSUB- STANTIATION}

Any philosophical or theological concept is formed and presented by, in and through the language. The totality - or, rather, sheer plurality - of innumerable concepts and notions "lives," and is to be found, in a number of languages, whether extinct or alive. The linguistic (phonetic, grammatical, syntactical, lexical) aspect is always joined to the conceptual (culture, worldview, specific system of thought) and, thus, calls for translation(s) as continuing (re)interpretation, (re)rendering, and (re)appraisal of a concept, an idea or a composition of ideas.

The awareness of this linguistic and conceptual challenge, emerging and in fact permanently active in the realm of culture, philosophy, and theology was brought to the fore by the proponents of the "translational turn" [Bachmann-Medick 2009; Cassin 2004c; Dünne... 2013b]. It has taken place quite recently but its consequences are already felt in the European intellectual milieu, though a lot is yet to come. It is this movement, started by Barbara Cassin [Cassin 2004b; 2007; 2014] and her international colleagues, that introduced and popularized the notion of an untranslatable (un intraduisible), which refers to a term, expression, syntactical or grammatical entity, or notion, that has to be constantly (not) translated and (not) retranslated. In Cassin's own words, "Parler d'intraduisibles n’implique nullement que les termes en question, ou les expressions, les tours syntaxiques et grammaticaux, ne soient pas traduits et ne puissent pas l'être - l'intraduisible, c'est plutôt ce qu'on ne cesse pas de (ne pas) traduire” [Cassin 2004b: 17; 2007: 199].

In my view this notion can be used to analyze not only the interplay, interdependence, and multifaceted correlation between the living languages of culture and philosophy (les langues naturelles, les langues de culture) but also the phenomena pertaining to the historical languages of culture and philosophy (les langues de l'histoire européenne) [Cassin 2007: 198-200]. Both goals were achieved in a project of Vocabulaire européen des philosophies. Dictionnaire des intraduisibles, though it was done in a more generic fashion, with a bigger picture in view. The historical-philosophical research was not done in much detail, which is very understandable - many things cannot be covered within a one-volume oeuvre. But it also means that the concept of "untranslatables" still has a potential for "stretching", employing, and applying to specific research objects for instance, the medieval scholasticism. Hence, my conviction of the need for a further

(C) R. Tkachenko, 2016 
elaboration of this linguistic and conceptual tool in the realm of histories of philosophy and theology.

This is why I intend to take a peculiar philosophical-theological theory forged in the Middle Ages, offer its exposition, and analyze it against its double conceptual (Christian religious vs. Aristotelian philosophical), as well as double linguistic (Latin vs. translated Greek), background. The theory in question is that of transubstantiation or the Eucharistic change. The author studied is Thomas Aquinas. The thesis defended is that the concept of transubstantiation as explained and argued for by Aquinas is an untranslatable indeed - a thomistic untranslatable. By this I mean that it is a unique reinterpretation (in Latin) of Aristotelian language of being and change (in Greek), which results in a conceptual innovation that has some inherent problems as well as creative and promising inventions.

Thomas engages the process of reflection de conversione panis et vini in corpus et sanguinem Christi (on "the change of the bread and wine into the body and blood of Christ"), which is the title of this section of the Summa Theologiae ${ }^{1}$ (hereafter ST) by asking several specific questions. ${ }^{2}$ They form the structure of the section and sound like this:

1. «is the Body of Christ really and truly in this sacrament or only in a figurative way or as in sign?

2. does the substance of the bread and wine remain in this sacrament after the consecration?

3. is the substance of the bread, after consecration, annihilated or reduced into one of the four elements?

4. can the bread be changed into the body of Christ?

5. do the accidents of the bread and wine remain after?

6. does the substantial form of the bread remain after the consecration?

7. is this change an instantaneous or a successive one?

8. is it true to say, "The body of Christ comes from the bread"?»"

As the articuli unfold one after the other, the arguments and aspects of St. Thomas' eucharistic thinking come to the fore and create a more and more picturesque view of

${ }^{1}$ Hereafter I will primarily refer to the Latin text and English translation of the Summa theologiae III, Quaestio 75 as given in [Thomas Aquinas 1965: 52-91] (hereafter - TA).

${ }^{2}$ Interestingly, he announced one set of questions but then chose to work with another one: he refused to follow his earlier pattern of thought as found in the Scriptum due to some unknown reasons and produced a revised version of the questions-articles. See (TA 52-53). Here I list only the actually formulated questions.

${ }^{3}$ Hereafter I quote the English translation in the main text and give the Latin original in footnotes. The just-mentioned questions are formulated by St. Thomas in the following manner:

...hos quæeruntur octo:

1. utrum in hoc sacramento sit corpus Christi secundum veritatem, vel solum secundum figuram vel sicut in signo;

2. utrum in hoc sacramento remaneat substantia panis et vini post consecrationem;

3. utrum substantia panis post consecrationem hujus sacramenti, annihiletur, aut in pristinam materiam resolvatur;

4. utrum panis possit converti in corpus Christi;

5. utrum in hoc sacramento remaneant accidentia panis et vini;

6. utrum, facta consecratione, remaneat in hos sacramento forma substantialis panis;

7. utrum ista conversio fiat in instanti vel fiat successive;

8. utrum haec sit vera, 'ex pane fit corpus Christi'.

(TA 52-53). 
Aquinas' theory. But this smaller picture should be contemplated in the frame of a bigger picture.

\section{The big picture: the theological and philosophical background}

It is very important to understand the purpose, starting points and also some problems, which determined or motivated St. Thomas' thinking on the issue of the Eucharistic change. I consider these to be important and useful preliminaries.

Purpose. As the historical-theological context, as well as the content of the text (cf. ST III, q.73, 75), indicates, the Dominican theologian did not try to astonish the world by creating a super-sophisticated semi-Aristotelian theory about the eucharist. Rather, his interest in the explicating the mystery of the eucharist was dictated by the Church's need for such a doctrine and his own view of the "sacramental economy" [Walsh 2005: 361] wherein God's salvific activity on earth is wed to the natural laws of the world and, hence, divine grace perfects the nature. This was believed to be realized in the sacraments, which uniquely unite God and man.

It is here that the main eucharistic concern of the time lies: ${ }^{4}$ after the Eucharistic controversies of the ninth and eleventh centuries and the semi-dogmatic - or, rather, terminological - decision of the Fourth Lateran Council (1215) ${ }^{5}$ it was necessary to conceptualize the "sacramental signification as "real presence"” [Leone... 2014: 15]. It was then that the term "transubstantiatio" emerged and was officially applied to the doctrine of the Eucharist. The order of articles in the Quaestio dedicated to the topic of eucharistic change (ST III, q.75, art.1f) seems to betray this purpose: to formulate the doctrine of the Eucharistic change so that it would clearly support the Christian belief in Christ's full, true and real presence in the Sacred Gifts of the altar [Cf. Walsh 2005: 360]. Yet, his way of achieving the posited goal was very different from that of his predecessors.

Theological presuppositions. This purpose was, in fact, dictated by several thenasserted theological convictions. They may be listed in form of short theses, as Marilyn Adams suggests [McCord... 2010: 85-87; Cf. Prusak 2014: 239ff]:

- Jesus Christ himself instituted the rite of the Eucharist and explicitly indicated that his real body and blood are somehow (really) present in the bread and wine of this Holy Communion.

- However, his real physical human body - murdered, raised from the dead and glorified - has ascended with its divine Owner into heaven and is locally present there.

- Nonetheless, the Catholic Church believes that "by means of the consecration, the true Body of Christ (the very one that was born of Mary and crucified) comes to be 'on the altar', 'contained by the sacrament'” [McCord... 2010: 86].

\footnotetext{
${ }^{4}$ See an excellent and concise overview of the key turns in the evolution of the "real presence" issue up to the 13th century in [Prusak 2014: 231-249]. See also [Hägglund 1968: 155-158; Marenbon 2007: 118-119].

${ }^{5}$ It should be remembered, that the Fourth Lateran Council did not dogmatize the doctrine of the transubstantiation, for there was no such a theory of doctrine at that time - it was Aquinas that invented its first complete version. However, the Council presided over by Pope Innocent III did introduce the term itself, as was indicated in the first chapter of the given thesis. So, the conciliar decision was not really dogmatic, although it 'blessed' the specific word - the transubstantiation - that was later used for theological research and, much later, for dogmatic constitutions on the subject (the Council of Trent, 1545-63). So in, for example, [McCord Adams 2010: 89n5].
} 
- The Church also admits that the (accidental and sensually perceived) properties of both bread and wine remain the same after the consecration as they were before.

- Thus, it necessary to hold to the belief that Christ's flesh and blood are invisibly present where the (species of) bread and wine are visibly present.

These theses were a kind of inevitable starting points for and the necessary theological background behind a theological inquiry into the nature of the mass. Thomas Aquinas never articulated that openly, but all these convictions implicitly shine through his reasoning in the questions 75-78 of the Summa.

Theoretical problems. There were two sets of problems that had their bearing upon the issue of conceptualization of the transubstantiation. One was theological and another one philosophical.

The theological problem was connected with a number of requirements for a theory of the sacramental change. Firstly, although the doctrine of real presence had been liturgically accepted and officially established, there existed several interpretations of it. For instance, some taught the "spiritual presence" theory wherein Christ was thought to be present only spiritually (spiritualiter), being absent in reality; some others insisted in some kind of rude physicalism, which implied that Christ was present in the host physically (per modum corporis or per modum loci), that is, his real human body somehow appeared on the alter under the species of the bread and wine; also some opted for a sort of "real and substantial presence" theory, which stated that Christ was present in reality (secundum veritatem or vere) substantially (substantialiter), that is, the substance - in the sense of the "basic reality" by which the thing is what it is [Vollert 2002: 159] - of Christ's body was present in bread and wine of the altar. ${ }^{6}$

It is the last position that had been earlier introduced in a very basic form by Lanfranc of Bec and the fathers of the Lateran Council and was now picked up by Aquinas. Yet, even in this case several theories were available: ${ }^{7}$

- annihilation - theory according to which the substance of bread and wine disappears in order to give "room" for Christ's body which is really present afterwards;

- impanation - belief that Christ becomes hypostatically united to the substance of the sacramental elements so that both substances - that of Christ and that of the sacrament - remain joined to each other but not mixed;

- companation - more mysterious view that Jesus' body and the substance of bread are united to each other "in some unspecified way" and simply co-exist in the Communion;

- still unexplained transubstantiation - terminological neologism and semiofficial doctrine, which implied that after the consecration the species of bread and wine remain but the flesh of the Savior is "really contained" (veraciter continentur) under these external elements.

The Dominican thinker refused the first three approaches and chose the last one. Thus, he in fact had to "translate" and give a meaning to the term that already existed but was still unclear. Plus, he met difficulties in his attempt to join together the classic Augustinian sacramental language and the conceptual world of Aristotle's philosophy (the philosophical problem) [Padgett 2000].

\footnotetext{
${ }^{6}$ Basically taken from the ST III, q.75, art.1 as in (TA 52-59) and also [Vollert 2002: 158].

${ }^{7}$ Basically taken from [Vollert 2002: 158, 159-160] and (TA 58-59nA).
} 
The latter was playing a more and more significant and controversial role in the academia of the $13^{\text {th }}$ century as the "translation phenomenon" had already changed the set of authoritative scholarly sources and resources. ${ }^{8}$ The laborious effort of Spanish and Italian translators made available in Latin many forgotten or then-unknown texts of Aristotle, other Greek thinkers, and a number of Jewish and Arabic philosophers. Thus, the borders of knowledge and the world of philosophical ideas as medieval men knew it expanded drastically. This led unavoidably to a new theoretical challenge consisting in the need to appropriate "the whole range of new sources translated from the Greek and the Arabic" [Marenbon 2007: 205] and at the same time keep explaining the world and Christian doctrine theologically in the light of the new "scientific" - that is, philosophical and in that case primarily Aristotelian - data.

For Aquinas it implied the need to reconcile the peripatetic metaphysics with its precision of terms on the one side and the theological concept of transubstantiatio with its mixed semi-Augustinian and semi-Paschasian (or Lanfrancian) origin, influenced by the "medieval Germanization" and the developed taste for "the miraculous theology" in the West on the other side [Collura 2014: 155). The transubstantiation pointed out to the change of substance (trans-substanti-atio), which was quite an Aristotelian concept (ov่ $\sigma i ́ \alpha$, $\tau$ ò $\tau$ í $\tilde{\eta} v$ Eĩval). ${ }^{9}$ But it is well known that the Aristotle's idea of substantial change allows only for a change of form, without transformation of the substance or the primal matter per se, because this is the law of natural change (transmutatio naturalis). But this metaphysics is locked inside the almighty and all-determining mechanism of the natural world order there is no room for the Living God and supernatural miracles. Yet, the Christian faith - as well as Thomas Aquinas' personal worldview - is theo-centric and theo-based; therefore he set out for a rethinking of the conceptual framework to "save" the Lateran theology of transubstantiation [Bauerschmidt 2005: 291n21; TA 60-61nB, 64nB, 68-69nA].

In the next section I will offer an exposition of his thought on the subject and then weigh it against its Aristotelian background and Christian theo-logic. Then, finally, a few concluding remarks will be made.

\section{The key theses of the Question 75: the eucharistic change introduced and ex- plicated \\ I will investigate Aquinas' arguments each in its turn, following the order of ST's ar- ticles. This method allows for a tracing of the flow of his argumentation while staying as close to the text and the author's voice as possible.}

Article 1 (TA 52-59). Friar Thomas starts by asking a question about the reality of Jesus Christ's presence in the Eucharist (ST III, q.75, art.1). He answers it positively and states that the Savior's body is present in the host "not merely as by a sign or figure, but in actual reality as well” (non solum in significatione vel figura, sed etiam in rei veritate). By this crucial phrase Aquinas apparently demonstrates that he does not deny that the mass has some symbolism imbedded: it is indeed a sign. But, at the same time, it is more than just a sign [Cf. Bauerschmidt 2005: 285n1, 287n7]: it is a combination of both (1) the symbolic function, as the eucharist signifies Christ and reminds people about his sacrificial death, and (2) the "realistic" function, as the eucharist "transmits" or, in Aqui-

\footnotetext{
${ }^{8}$ See good overviews of this tendency, its origins and philosophical significance in [Marenbon 2007: 169-170, 210-212, passim; Gutas 2010; Mavroudi 2015].

${ }^{9}$ For a detailed overviews of the formation, meaning and later transformations of these Aristotelian and partly Neo-Platonic “untranslatables” see [Cassin 2004a: 423-424; Courtine 2004; Courtine \& Rijksbaron 2004].
} 
nas’ language, “contains” 10 the real Christ. Thus, Thomas seeks to stay in accord with the Augustinian understanding of the Holy Communion with its distinction between signum (immanent “sign”) and res sacramenti (transcendent “thing”) [Leone... 2014: 15] and a strong idea of Christ's real presence within the host.

Aquinas even comes to the conclusion that Christ should be present in the Eucharist, because (1) the Holy Communion is the sacrament of "the New Law" (this is, the Gospel) and, as a consequence, must be different from the sacraments and sacrifices of "the Old Law," which were signs only. Since Christ fulfills the Old Testament law, he adds realness to all those signs, and therefore the new sacraments are more than just symbols. It is fitting also (2) because of his love to his followers and according to the principles of friendship presented by Aristotle - that "friends should live together" (maxime proprium amicitiae est convivere amicis) - which require for a never-ceasing presence of both parties (conjunctio Christi ad nos). This rule, as Frederick Bauerschmidt notes, has to express the idea that a normal human friendship usually implies close and regular interaction between those involved; and this fellowship always occurs in physical dimension, employing "the medium of our bodies” [Bauerschmidt 2005: 287-288n8]. This fits perfectly into the lifestyle of ordinary humans and, in Aquinas' opinion, must work equally well when the relationship between the divine-human Jesus and merely-human Christians is in question. Plus, (3) such a miraculous presence is useful for people's faith (hoc competit perfectioni fidei) for, still, Christ is in the bread and wine bodily but invisibly (invisibiliter): only faith is able to accept this doctrine. Thus, this eucharistic presence encourages people to exercise their faith and, as a result, grow spiritually (speaking in contemporary Christian terminology).

Having formulated these arguments and mentioned some ancient writers as authorities who supported this view, Aquinas concludes that it is right to believe that Jesus is truly (secundum veritatem) present in the eucharist and assert the "reality of Christ's body" (veritatem corporis Christi). Even the possible objections cannot stand against it.

For example, he thinks that neither the notion of "spiritual understanding," nor that of "spiritual presence" found in Augustine's text are able to cross out the "real presence" idea, since the term "spiritually" (spiritualiter) can mean simply "invisibly" (invisibiliter) and "by the power of the spirit" (per virtutem spiritus). Moreover, the notion of spiritual does not necessarily exclude material aspect, as was confirmed by the Incarnation. On the contrary, "the spirit united to the flesh" brings great benefit.

As for the mode of Jesus' presence, it cannot be regarded normal in an ordinary sense, because Christ is not there physically (per modum corporis): the "location language" might be used with regards to Christ's "natural appearance” (quod videtur in propria specie), but must be avoided in the context of sacramental realities. In fact, Christ's physical body is localized in heaven, but the eucharist contains it not "locally," that is "in the way a body is in place.” The latter would imply a certain correspondence between the body's constitution and limits of physically determined space (sicut corpus in loco, quod suis dimensionibus loco commensuratur). But that is not the case: rather, the Savior appears in the sacrament in a special supernatural way (speciali modo, sicut in sacramento) guaranteed by God's power. The explanation of this way is to be given in the subsequent articles.

\footnotetext{
${ }^{10}$ Latin contineo is used here to denote an idea of "being present inside," but without notions of "being confined," "limited," or "restricted" to a containing place (TA xxiin); [cf. Collins... 1997: s.v. “contineo;” Oxford Latin Dictionary 1968: s.v. “contineo”].
} 
As for this article's theses, it is obvious that Thomas Aquinas establishes here the possibility, let alone necessity and benefits, of Christ's real presence in the eucharist, and rules out some misconceptions (about Christ's physical and locally-measured mode of presence and extremely symbolist understanding of the mass). But the text reveals that in St. Thomas' view this doctrine must be founded on the Christological basis. ${ }^{11}$ It is seen in his mentioning the union of spirit and flesh in Christ that has to provide justification for his two-sided (sign plus real thing) model of the mass' nature. But what is this sacramental and special mode of Christ's presence?

Article 2 (TA 58-63). Here (ST III, q.75, art.2) St. Thomas introduces two alternative interpretations: either Jesus Christ should really and bodily descend from heaven to the earth by the local motion, or the very substance of bread or wine (that is, their form and matter) must change into the substance of his body. The logic is quite simple here: "[A] thing cannot be where it was not before, except by being brought in locally or by something already there being changed into it." ${ }^{12}$ But the first option is definitely wrong - in order to make it true, Christ has to leave the heaven and become "dispersed" across different locations. The first proposition is contradicted by the Christian teaching and the second by logic. Hence, only the second theory is acceptable and, thus, the doctrine of conversion of the bread and wine into the body and blood of Christ finally emerges. The term "conversio" here means that after the consecration the essential inner constitution (substantia) of the eucharistic elements drastically changes: what was earlier the bread and the wine is now transformed into the body and the blood of Jesus, although the external qualities of the bread and wine remain untouched. In other words, "[t]he presence of Christ in the Eucharist is a substantial presence after a substantial conversion of the substance (what makes a thing be what it is) of bread and wine” [Prusak 2014: 247].

Lexically, conversio may be considered as a synonym of mutatio, expressing the same idea of a change. Nevertheless, they are not always identical. In the first place, mutatio often signifies the wide range of (natural) changes, which might denote either partial as well as thorough change, or an exchange between two parties whereby both alter their previous characteristics, whereas conversio here denotes a total change, a "turning around" or transformation of one particular thing into the other [Oxford Latin Dictionary 1968: s.v. “mutatio,” “conuersio, “conuerto;” Collins Latin Dictionary 1997: s.v. "mutatio", “conversio," "converto”]. In the second place, the conversion is always seen as an act with two particular termini or points: a terminus a quo ("the-term-fromwhich") and a terminus ad quem ("the term-to-which"), where the former means that which is converted and the latter that into which something is converted [McCord... 2010: 88; Muller 1985: s.v. "conversio"]. ${ }^{13}$ For example, in the process of a conversionlike change of the eucharist the substantia of the bread and wine would be called theterm-from-which, and the substantia of Christ's body and blood the term-to-which - the

11 [Bauerschmidt 2005: 289n14; cf. Leone... 2014: 14]. Leone and Parmentier agreeing with Kessler, even say that "it was medieval Christianity's belief in the dual nature of Christ, a mysterious union of human and divine, that provided religious viewers' "inner eye" with a theory of artistic representation in which the physical image and the transcendent prototype are simultaneously distinct (representationally) and united (theologically).” Thus, they stretch the Christological basis from its theological realm to the one of aesthetics and artistry.

${ }^{12}$ Non autem aliquid potest esse alicubi ubi prius non erat, nisi per loci mutationem, vel per alterius conversionem in ipsum (TA 60-61).

${ }^{13}$ Cf. ST III, q.75, art.3, ob.2. 
one is transformed into the other. As a result, Ambrose's saying sounds sound for Aquinas: "Although we see the appearance of bread and wine, we should believe that, after the consecration, there is nothing other than the flesh of Christ and his blood." ${ }^{14}$ One thing is seen, another is contained, or, as Nicholas Collura concisely expressed it, "[t]he inner logic of the Eucharist is different from its visible effects” [Collura 2014: 153]. But what exactly happens with the substance of the two Eucharistic elements?

Article 3 (TA 62-69). It seems that, if the substance of bread and wine is to be changed into something else, it must disappear before. In other words, if this substance exists no longer after the consecration, it must have turned into nothing (annihilated) before the substance of the Son of God's body has taken its place. Hence, in this article Aquinas wants to deal with the notion of annihilatio and explain how it relates to the eucharistic change.

In fact, although prima facie annihilation always means destruction and elimination of a thing [Muller 1985: s.v. "annihilatio;” cf. Cassin 2004a], there are two possible ways of understanding the annihilatio in the Aristotelian metaphysical pattern. It should be either something's resolution or reduction into primary matter (that which does not actually exist without the form) or a total dissolution of something into nothingness (that which does not exist at all, purum nihil). At any case the annihilation is necessarily entailed by the Aristotelian notion of substantial change. But St. Thomas thinks that conversion does not imply annihilation (ST III, q.75, art.3).

In his view it is theologically improper to say that God needs to destroy something before he is able to make something new out of it, because then he should be said to cause the complete non-existence of something, which is impossible for God. ${ }^{15}$ Besides, annihilation as the substance's resolution into the primary matter (specifically, the four elements: air, fire, earth, and water) is equally impossible because then the matter should remain without the form, but no matter exists without its form. Thus, the principles of the Aristotelian metaphysics support the wrongness of the annihilation theory.

The right view, promulgated by Aquinas, consists in belief that "the substance of the bread or wine remains until the last instant of the consecration. In the last instant of the consecration we already have the substance of the body or of the blood of Christ." ${ }^{16}$ The two elements do not turn into nothing before Christ's body takes place of their substantia - they exactly turn into the substance of this body (non... annihiletur, convertitur enim in corpus Christi). Such a conversion is rightly labeled "the substantial change" or "transubstantiation" as different from the "accidental change."17

${ }^{14}$ Ambrosius dicit, in libro de sacramentis, licet figura panis et vini videatur, nihil tamen aliud quam caro Christi et sanguis post consecrationem credenda sunt (TA 60-61).

${ }^{15}$ Aquinas states this in a form of quotation from Augustine, but does not clarify why it is the case (ST III, q.75, art.3, s.c.).

${ }^{16}$ Similiter etiam substantia panis vel vini manet usque ad ultimum instans consecrationis. In ultimo autem instanti consecrationis iam est ibi substantia vel corporis vel sanguinis Christi... (TA 66-67).

${ }^{17}$ In the Aristotelian framework of the hylomorphic theory of reality, the substantial change means that "the substance is changed in its depths, where primal matter (pure potentiality) is actuated by substantial form" (pure actuality) whereas the accidental change refers to the change of only the thing's secondary qualities, the accidents (appearance, quantity, quality, etc), without any alteration of the substance. The first type of change implies the profoundest transformation of being while the second one is but a surface modification. A suitable examples of both types of change may be easily found in our reality: (i) heating of some water whereby the cold water becomes the hot water, still remaining a water, would be an accidental change, and (ii) acetification of wine - if the bottle of it was left open for a long while - in result of which it would become vinegar is a substantial change. 
However, the promulgation of the type of change, which does not need to imply a physical decay or a metaphysical annihilation of one substance (particularly, its substantial form) before the other substance (this is forma substantialis) is unthinkable in the Aristotelian physics and metaphysics. Every substantial change implies the conversion of one form into the other form, but it means that the first form must disappear - be annihilated - so as to enable the second to "pop up" and take the former's place (TA 67$68 n G, 68-69 n A)$. But here Aquinas deviates from the Aristotelian reasoning and starts his "escape into mystery” and the process of creating an “Aquinatic untranslatable.” His key argument in this article has nothing to do with the naturalistic reasoning: God cannot be a creator of nothingness for this would entail a conclusion that God is a destroyer who brings disaster to the reality, which he himself had created and with which he was earlier pleased. Such thinking is destructive to theology and so, Thomas Aquinas does not allow for any idea of annihilation in his version of the substantial change (of the eucharist).

But it is exactly this theological kernel that is alien to the Aristotelian metaphysics: there is no God who creates everything out of nothing without having created this "nothing" before, but there is the idea of necessary natural order reigning over the world. "According to Greek philosophia necessary reality is simple, even simplistic, absolute and static, harsh and often cruel, but the notion of newness is an insult according the old way of thinking, for everything is the same and has its own time. True change is impossible" [Vos 2009].

At the least, the true change of the concept of change is indeed impossible: the ordo naturalis requires that the formal change ought to necessarily imply annihilation as an intermediary stage between the end of existence of one substance and the emergence of another substance. Aquinas tries to break this vicious circle and introduce the different notion of conversion - that which would allow for a direct and immediate substantial change of bread and wine's substantice into those of Christ's flesh and blood [Kerr 2009: 98; cf. Nichols 2005: 12]. Certainly, this unusual reconceptualization of the conversio-theory rests on the notion of the supernatural power of God, and this supernaturalism reveals the Augustinian and Neo-Platonic motifs in St. Thomas' writing. But is it really possible?

Article 4 (TA 68-73). Aquinas tries to prove this in his fourth articulus (ST III, q.75, art.4) where he reinterprets Aristotle's idea of substantial change and adapts it to Christian theology.

In Aristotelianism the substantial change is identical with the formal change (mutatio formalis) and, hence, involves two logically distinct stages: (1) "the reduction of a first form into the potentiality of matter"18 and (2) the "simultaneous eduction of a second form out of the potentiality of matter." Thus, "form passes into form” while matter remains the same, ${ }^{19}$ so that, in Aristotle’s own words (Physics I, 6), "change is the actuation of that which is still in potentiality" (motus est actus existentis in potentia). ${ }^{20}$ But in order to better understand both the terms mentioned and the conception of change presented several clarifications should be made.

Short but clear explanations and examples are taken W. Barden's comment in (TA 64nB), and P.J. Fitzpatrick's illustrations in [FitzPatrick... 1995: 18].

${ }^{18}$ Here the term "reduction" is a full synonym of "annihilation" and, thus, has been just discussed in the preceding paragraphs.

${ }^{19}$ Formulation by W. Barden in the footnotes to (TA 67-68nG, 68-69nA).

${ }^{20}$ Aristotle, Physics I, 6. 201a10. Quoted in ST III, q.75, art.4, ob.1 (TA 68-69). 
First of all, for Aristotle, “[a]mong corporeal things, change is potency actualization, in which what is potentially F comes to be actually F” [McCord... 2010: 7]. This rule always works when the substantial or accidental change takes place. Whether cold water turns into a hot water or a measure of wine turns into vinegar, in both cases there is an obvious (natural) potency of the antecedents to become the consequents: cold water can become hot, and wine can become vinegar.

Moreover, the Aristotelian identification of potency with the matter and actualization with the form help to better understand the notion of substantial change in its proper sense: when the substance $A$ is said to be converted into the substance $B$, it means that the substantial form $A$ that normally actualizes the matter "descends into" the potency of this matter, but at the same moment the substantial form $B$ "comes out" of this very potency of the matter and immediately actualizes this matter, taking over the $A$ 's place (TA 68-69nA). To illustrate this Aquinas employs an example of air turning into fire (ST III, q.75, art.4, ob.2): when the air, being in certain place and measure, turns into the fire (which did not exist in the beginning), the form of air is replaced by the form of fire, but the matter remains the same; the matter of air simply becomes the matter of fire - a very plain idea. The same explanation may be applied to the example of wine going sour - the forms changes, the matter remains [FitzPatrick... 1995: 19].

Furthermore, for Aristotle, "change is intelligible only because there is something that persists through the change" [McCord... 2010: 7] - there must be a link between two sides or termini of the change. When one heats the water (the accidental change of quality), the substance of water remains the same; and when one lets wine be transformed into vinegar, the matter is always there [FitzPatrick... 1995: 19]. Otherwise, there is no change or conversion but only an evaporation of a thing and/or replacement of one complete thing with another complete thing. Either the form or the matter should stay unchanged to testify to reality of change occurred. This is how Aristotelian metaphysics perceives substantial (and accidental) changes [McCord... 2010: 89-90].

But Aquinas does not accept this interpretation of change and even without explicitly refuting the Philosopher proposes his own version of the change theory. Firstly, since the eucharistic change is supernatural, it is absolutely possible that the ordinary rules of change do not work there, because Aristotelian metaphysical logic relates only to natural changes. This is his "verbal" or semiotic solution, which continues the already started escape into supernaturalism. After all, "the chief work of the Eucharist is not ours; it is God's” [Collura 2014: 165].

Secondly, since every agent in the world acts according to his abilities - and one's potential to cause changes ("the order of action") is determined by one's level of perfection and place in the hierarchy of beings ("the order of being") ${ }^{21}-$ it is inevitable that "the action of every created agent has a definite and limited range" (cuiuslibet agentis creati actio fertur super aliquem determinatum actum). However, the conversion of the bread and wine is performed not by creatures, but by God who is "unlimited action" (infinitus actus) with equally unlimited abilities. So, it is he who can, and eventually does, cause the substantial change in which "the complete substance of this is changed into the complete substance of that" (tota substantia huius convertatur in totam substantiam il-

21 "The higher a thing is in the order of being, the more actual it is, the greater is its power of action. To exist is to be able to cause and, where creatures are concerned, to exist demands the exercise of causality. Agere sequitur esse, action follows on existing” (TA 70-71nF). 
lius). Such a statement is true in the context of theology, but it does not fit at all with the Aristotelian model of change: philosophically speaking, Aquinas' proof is impossible and unimaginable, but, theologically speaking, he has the point.

Thus, Thomas Aquinas in one move - namely, the addition of the divine element into the Aristotelian conception of substantialis conversio - assumes both the possibility of such a change and its character. At one moment of time the whole substance of bread is totally transformed into the whole substance of Christ's body. This change evidently violates the principles of Aristotle's theory of change, for (1) there is no potency because neither bread, nor wine has the potential ability to become Christ's body or blood, (2) nor is there any real structural link between the two stages of the eucharistic conversion. Rather, it is said that the whole substance - both the matter and the form - of bread and wine convert into the whole substance - also both the matter and the form - of Christ's body and blood, respectively. In fact, the only link that connects what was before and what is now after the consecration - which is the very moment of change - is the appearance of bread and wine on the altar. But the accidents cannot be considered a metaphysical "bond" in both substantial and accidental changes. In brief, (a) "accidents cannot migrate from subject to subject," [McCord... 2010: 24] and (b) "there is no such thing as a free-standing 'accident' [because a]n accident, like the color red, must be a quality of, or inhere in, some substance" [Nichols 2005: 12]. Hence, it seems that the eucharistic conversion must be, indeed, an absolutely unique and abnormal example of the substantial change as "the changing of the whole being of a thing" (conversio totius entis).

In other words, Aquinas takes an empty theological concept of transubstantiation and a full of meaning philosophical concept of substance and its potential changeability and then imports the latter into the former. But by doing this, he relocates the whole idea of substances and changes from the "philosophical language game” playground to the theological one. But this change of conceptual world leads to the change of rules. Specifically, the accidents appear to be more "powerful" and potentially independent than it was allowed by the Aristotelian framework. But what exactly about the accidents of the bread and wine?

Article 5 (TA 72-77). In the fifth section (ST III, q.75, art.5) the Dominican theologian takes into account several difficulties with his version of the doctrine of the eucharistic change. First of all, as was just said, logically and metaphysically speaking, it is impossible to imagine that the accidents remain after a thorough change of their "ascribed" substance because substance is "naturally prior" to accidents as they depend on it. Besides, it looks like a deception of people, for their senses perceive the realness of bread and wine, although this is false - there is no bread and wine after the prayer of consecration.

Yet, St. Thomas answers that there would not be any deception because the senses are not the only source of knowledge for human intellect: there is also faith (in the Revelation) that plays a role. And since the senses are concerned with accidental phenomena (what is seen, what is felt, what is smelled), and the faith with the credenda, the things to believe, there cannot be any contradiction between them. Thus, faith and senses are believed to correspond to two different layers of reality: the latter deals with the sense-phenomena only (what one could call the "ritualized manifestations" of the transcendental [Leone... 2014: 13]) while the former is able to approach the nature of things as it is revealed from Above (what one could call "discursive theorizations of semiotic mediation" [Ibid.]). Hence, quite paradoxically, Aquinas thinks it is normal that the senses adequately perceive the reality (there is only bread and wine on the altar) and the faith adequately interprets this reality (there is no bread and wine but only Christ's body). How can this be? 
In Aquinas' view, the accidents' continuing presence in the sacrament after its consecration is completely possible, because every accident depends on its substance as its causa in a sense, for, still, the First Cause of everything (causa prima omnium) is God, and ultimate dependence on him is the major principle of the cause-effect relations. It means that the accidents always inhere in, and are determined by, their substance [FitzPatrick... 1995: 18]: if the ball is round and white with black stripes, it is because his creator had such substantial form - the whole shape or blueprint of the ball - in mind, and this form determined that appearance. But even if the ball's accidents are constituted by its substantial form as the immediate cause, everything in the world has been created and is maintained by the First Cause. Hence, as William Barden notes, the "accidents depend on the substance in which they are. But the accidents - and the substance - depend upon God - from whom they are" (TA 76nA).

Therefore, natural laws cannot be an obstacle for God because "the first cause can suspend the second cause, and thus keep accidents in existence in the absence of the substance of which they were the accidents" but, again, such a move is possible only within the christened Neo-Platonic scheme of reality, since Aristotle's conception does not have room for this, as Fergus Kerr indicates [Kerr 2009: 98-99]. So, Thomas Aquinas seems to take the Aristotelian terminology of substances, accidents, and causes and let them pass through the Augustinian/Neo-Platonic lens [Ibid.]. As a result, it looks "proved" that the accidents of bread and wine might remain even after the transubstantiation, but the question arises whether such a methodological step - from one metaphysical model into the other - is allowed. Perhaps, it is but an example of the Thomistic attempt at a theological synthesis of Christian (Augustinian) and pagan philosophical (Aristotelian) worldviews, which looks as ambiguous as it is fascinating.

Nevertheless, the theologian from Aquino has something more to say: it is not only possible that the accidents of the two elements remain - it is necessary. The appearance and flavoring qualities of the bread and wine have to remain, because (1) men do not eat human flesh, (2) otherwise the "unbelievers" (infideles) could make this sacrament an object of contempt, and (3) such a miracle serves well in "increas[ing] the merit of our faith" (proficiat ad meritum fidei). So, God allowed for the substantial change and the accidental stability in the eucharist out of his love and care for his people.

This interpretation sounds very theological and even beautiful. Yet, the whole theory's truthfulness rests not on its metaphysical and logical power but on a theistic argument. This article shows it quite clearly: the strict Aristotelian metaphysics does not admit even a possibility of the accidents' existence without their substance, and so, Aquinas, who knows that well but is bound to some theological presuppositions and requirements, has to ascribe this accidental stability to "a continuous miracle" [Nichols 2005: 12]. Hence, his theory of the eucharist becomes less philosophical and more theological: the supernatural change of the material elements' substance can be explained only with the constant appeal to miracles and God's omnipotence, because the normal physical and metaphysical rules do not work here - they simply fail to meet the theological presuppositions of Thomas Aquinas and the Church of his time. But being a good philosopher, the great Dominican does not reject the original peripatetic ideas - he simply translates them "to" his own theological language. But this being done, the outcome turns to be a unique untranslatable forged by the work of a Neo-Platonizing Augustinian spirit in person of Friar Thomas on the Aristotelian ground. 
In fact, with this article all the key points of Thomas Aquinas' theory of transubstantiation have been established. Yet, not all details were clarified and explained, and, therefore, the last three articles are dedicated to three relatively small issues, though the last section of the quaestio 75 gives some valuable hints for a better understanding of St. Thomas' eucharistic theology.

Articles 6-7 (TA 76-85). Firstly, the author confirms that as "the complete substance of the bread is converted into the complete substance of Christ's body, and the complete substance of the wine into the complete substance of Christ's blood" (ST III, q.75, art.4), ${ }^{22}$ and then the substantial form of the bread becomes the subject of this conversion as well (ST III, q.75, art.6). It does not remain after the consecration, since the substantial form of the Savior's body emerges "out of" it and takes its place, and this is perfectly in accordance with the form of the sacrament of the altar - the words "Hoc est corpus meum." Such a "formal removal theory" is, of course, alien to the Aristotelian metaphysics of change, because it always requires for an "underlying subject" (TA 68-69nA) which ought to stay stable. But the Dominican thinker rules out the possibility of such subject's continuance (cf. ST III, q.75, art.4, ad 1) and keeps insisting on the "absoluteness" and "thoroughgoingness" [McCord... 2010: 90] of the eucharistic conversion of one substance into the other one.

After this, Aquinas gives some arguments in support of his already mentioned belief in the instantaneous character of change of the bread and wine (ST III, q.75, art.7). It seems that there must be "an intervening time" (tempus medium) between the moment $T_{1}$ when the substances of two material elements are still there while Christ's bodily elements have not yet "come" in, and the moment $T_{2}$ when the substance of Christ's body is already there while the form and matter of bread and wine have just "gone", but such an opinion is wrong. The overemphasized difference between "becoming" (fieri) and "having become" (factum esse) and the too simplistic a view, that successively pronounced articulation of Jesus' words of institution entail successive conversion, are not correct as well.

The substantial change in the rite of the Holy Communion must be instantaneous because, (1) this transformation is performed by the Agent of an unlimited and infinite power, who does not need any intervening period of time to produce something and, hence, acts instantly; (2) "becoming" and "having become" may easily coincide (simul est fieri et factum esse), like, for example, in the case of becoming illuminated (illuminari) and having become illuminated (illuminatum esse) by the sun; ${ }^{23}$ and (3) it is not the way of pronouncing words that matters for the sacrament, but their meaning and significance (verborum significatio) that is efficacious for sacramental phenomena. Therefore, one has to conclude that the eucharistic change simply "takes place in the last instant of the utterance of the words," without any succession. ${ }^{24}$

${ }^{22}$ Nam tota substantia panis convertitur in totam substantiam corporis Christi, et tota substantia vini in totam substantiam sanguinis Christi (TA 72-73).

${ }^{23}$ Aquinas employs here the example of 'being illuminated' and 'having become illuminated' as a proofcase for instantaneity of substantial change, although this example does not speak of such change. Therefore one can question the adequacy of this proof. But I suggest that the example should not be necessarily regarded as a factual proof; rather, it is a proof by analogy: the instantaneity of the transsubstantial change of the mass is analogous, that is similar, to the instantaneity of the accidental change (change of being in position or state) of being/having become illuminated by the sun.

${ }^{24}$ Ad tertium dicendum quod ista conversio, sicut dictum est, fit in ultimo instanti prolationis verborum, tunc enim completur verborum significatio, quae est efficax in sacramentorum formis. Et ideo non sequitur quod ista conversio sit successiva (TA 84-85). 
Article 8 (TA 84-91). Here Thomas d'Aquino comes to a conclusion (III, q.75, art.8) and states that it is absolutely acceptable now to say that "the body of Christ comes from the bread" (ex pane fit corpus Christi), if the terms are accurately interpreted. In particular, such a statement is correct if the preposition "ex" is understood in its proper Latin sense (this is "from," which refers to "nothing more than order" and could be also fittingly translated as "after"). ${ }^{25}$ At the same time "panis" signifies "not the substance of the bread, but in a vague sense that which is contained under the appearances of the bread" (nomine panis non intelligatur substantia panis, sed in universali hoc quod sub speciebus panis continetur). So, one is allowed to say: "the body of Christ comes after the bread" or "the body of Christ comes from what is sensed/is felt/tastes like bread," or "the body of Christ comes from that bread-like thing." What is indicated here is nothing more than that $B$ comes after $A$. There is no causality apart from the divine causality, and, so, it is wrong to conceive the panis or vinum as the raw material out of which the Christ's body emerges. Aquinas speaks here about the logical and temporal succession, which he finds in the classical Christian interpretation of the Genesis 1-2. The formula of creatio ex nihilo for him means exactly this - that the world comes not "out of," but "after" nothing - and thus serves as the model for his own sacramental theorization.

This is why it would be wrong to state that "the body of Christ comes out of the bread” where English "out of” corresponds to the Latin "de,” because this term usually for Thomas Aquinas at least - indicates the material cause (designat causam consubstantiallem) out of which both the first and the second forms emerge, according to the Aristotelian view. But this theory would result in a statement, that "the body of Christ comes out of the same matter (or material cause) with the bread," which is impossible because the body of Jesus does need this corporeal platform for its coming out.

Hence, the statements about the extraordinary and mysterious change in the mass should be made carefully enough to differentiate between natural changes (mutationes naturales) and sacramental conversio, as well as between acts performed by creatures and caused by God. Only the second option fits into Thomas' eucharistic theology, which is based on an idea of the uniqueness of transformation of the bread and wine in the rite of the Holy Communion. It is different and exceptional even in comparison to the creation, let alone all natural changes (III, q.75, art.8, ad 3). But in fact the transubstantiation both resembles and is different from the natural change:

1) both imply conversion of an $A$ into a $B$, but - and here the first dissimilarity arises - in natural changes the "something" refers to the form whereas in the mass the "something" denotes the complete substance (of bread and wine and of Christ's body and blood correspondingly); and

2) both have "an identical element [which] survives the change" (remanet aliquid idem), but - and here the second dissimilarity lies - in natural substantial changes it is the matter that is found at "the two ends of change" [FitzPatrick... 1995: 19], whereas the miracle of the altar allows for only accidents' survival in the change.

Thus, there are more differences than real resemblances between the normal Aristotelian substantial change and the Thomistic transubstantial change: Aquinas clearly goes against the usual order of things that is elaborated by the Philosopher, ascribing many nuances of his theory to the providence of God expressed in the suspended secondary causality and intervening primary (direct divine) causality. But, of course, he still keeps

${ }^{25}$ Note on the correct translation is found in (TA $86 \mathrm{nA}$, italics mine). 
the terms and, partially, concepts of Aristotelian worldview. All the substances, accidents, forms and matter(s) do play their roles in the Thomistic synthesis even though sometimes they are used not in their normal way. Rather, their new use leads to an emergence of the conceptual innovation that would cause many reinterpretations and criticisms after its birth and later circulation.

\section{Analytical Conclusions}

The overall flow of arguments of the quaestio 75 leads us to a conclusion that, indeed, “Aquinas's understanding of Eucharistic conversion is primarily rooted not in Aristotle's metaphysics, but in a biblical metaphysics of creation from nothing, something that is quite alien to Aristotle's philosophy” [Bauerschmidt 2005: 290n17]. Although, in my opinion, it is perhaps too radical to say that the transubstantiation theory of Thomas Aquinas is rooted in the "biblical metaphysics of creation," it is evident that the account of Genesis 1 and the traditional Christian teaching about creation ex nihilo influenced his thinking about the Eucharist. In fact, an assessment of Aquinas' achievement in the area of Eucharistic theology should take into account not just roots but rather the theological foundation, the linguistic and conceptual tools, and the philosophical value of his transubstantiation theory. Only such a complex approach will do justice to this theory.

First of all, it goes without saying that St. Thomas' point of departure is ecclesial theology. Practically, it was the need to provide the church with a "discursive theorization" and "sophisticated metasemiotic reflection" [Leone... 2014: 13, 15] on an already proclaimed dogma that directed Aquinas’ work. Theoretically, the substantially theistic worldview, traditionally explained in Neo-Platonic Augustinian terms stood behind the whole of Thomistic thinking. Therefore, it would be impossible for him to avoid the "theological import" and the insertion of the divine causation into his reasoning over the eucharistic change. The Christian sacramentalism and the whole vision of the cosmos was built upon the non-necessitarian theocentric foundation: hence, the possibility for contingency, freedom and miraculous intervention of the divine, which were excluded from the major part of ancient Greek philosophies, including the "regenerate" Aristotelianism of the $13^{\text {th }}$ century [Vos 2010: 204-205].

But, secondly, it is impossible to deny that the terminological and, consequently, conceptual apparatus that Aquinas worked with in his thinking about the eucharist was not Neo-Platonic - it came from the Philosopher. And here it is critical to note together with John Marenbon, that Thomas Aquinas knew Aristotle really well, ${ }^{26}$ and his decision to "stretch" and creatively rework the peripatetic theory of change for the benefit of postNeo-Platonic Christian metaphysics was absolutely conscious.

He understood the purely Aristotelian conception of substantia and possible modes of its metamorphoses: namely, the already mentioned (1) conversio accidentalis or transaccidentatio wherein "the substance remained unaltered but the incidental properties or accidents change” [Muller 1985: s.v. "transubstantiatio”], and (2) conversio sub-

${ }^{26}$ He turns the reader's attention to "the contrast with another Aristotelian devotee, his teacher Albert, [which] is also telling: Albert had read Aristotle in the light of the Aristotelian-Neoplatonic systems developed in Islam, and he developed his understanding of him in discursive commentaries, near in style to Avicenna's Healing, although Averroes was an important source; Aquinas, who follows the model of Averroes's Great Commentaries, but with his attention more closely rooted to the text itself, sticks to presenting what Aristotle said - through his, Thomas's, eyes, certainly, but as an interpreter trying to make sense of the book in front of him” [Marenbon 2007: 237]. 
stantialis or natural transubstantiatio whereby the "substance is changed into another, as by decay or digestion, and both the substance and the accidents which inhere in it change" [Ibid.] whereas the matter remains unchanged. There was no third type of change, let alone an idea of supernatural intrusion. But the mechanisms of these two kinds of transformation silently witnessed to "the third logical possibility" [Ibid.] that would be parallel to transaccidentatio but would, in fact, go further than normal transubstantiatio. As a result, this hypothetic possibility was picked up and realized by Thomas Aquinas: he dubbed it the supernatural transubstantiatio (of the eucharist)

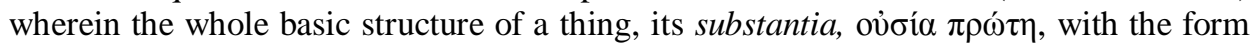
and matter included, would be separated from its accidents and thoroughly converted into the complete substance of another thing.

Richard Muller is right when he calls this option only logically possible, because actually it has nothing to do with the reality, as we know it. Nor is it in any sense Aristotelian. But Friar Thomas took this logical potentiality and turned into a theological and, by extension, philosophical actuality. In fact, the Thomistic quasi-Aristotelian transubstantiation theory was - and still is - so unusual and extraordinary that even today some Catholic (and, of course, Protestant and Eastern Orthodox) theologians refuse to accept it and, like P.J. FitzPatrick, think that it "takes terms devised to express change, and it puts them together in a way that makes no sense" [FitzPatrick... 1995: 19]. Fergus Kerr offers a more nuanced evaluation, saying that

this account of transubstantiation seems to collude with the skeptical metaphysical doctrine that the way that things appear is no guarantee as to how they really are. Such a radical denial of the common-sense realism that things are normally just as they seem does not only depart completely from anything that Aristotle could have conceived but seems to threaten the confidence that Thomas consistently shows in the reality of the world we inhabit. [Kerr 2009: 99].

Nevertheless, I suggest that the Aquinas' transubstantiation theory is philosophically interesting and thought-provoking - though not uncontroversial - and deserves a reappraisal and reappreciation. From the strictly logical and metaphysical perspective, there are indeed at least two inherent problems that remain unresolved in the theory:

1. Even if one forgets about the Aristotelian metaphysical categories, it is barely consistent to say that (a) the substance of the bread does not disappear, but passes into the other substance, and simultaneously affirm that (b) the substance of Christ's body takes the place of the bread's substance which underwent conversion, but still, the Christ's bodily substance does not emerges out of the previously present substance. How can it be that the substance $A$ is being transformed into substance $B$, but this $B$ does not come out $A$ ? It must be either a verbal confusion, wherein the select language fails to correctly describe what is going on, or a logical and terminological inconsistency which mistakenly calls a substitution "the conversion". ${ }^{27}$ Any kind of conversio can be properly called so only if something is really turned, transformed into something. One does not speak of conversion when $B$ simply comes after $A$, unless we simply accept the revolutionary redefinition of the term suggested by Thomas Aquinas.

${ }^{27}$ This is the logical consequence of (1) Aquinas' preference for the "ex pane fit corpus Christi" instead of "de pane fit corpus Christi," and (2) his denial of the annihilation of the first substance. 
2. The idea of accidental independence is also problematic [McCord... 2010: 245246]: although the accidents have to naturally inhere in (inesse) the substance because they do not have an existence (esse) of their own, God can temporarily suspend this rule and directly - this is, himself - provide for their existence outside their substance. Of course, God can act supernaturally, but is it proper in this case? It is proper for the accident to be dependent on the substance, because the latter is both material (as a substratum for the actually existing object) and efficient (as a foundation and guarantee of the accident's existence, so that as long as substance persist, its accident may continue to exist as well) cause of their existence [Courtine 2004: 406-411]. But if, in the eucharist, the bread's substance somehow disappears, then there arises a need for the accidents to "find" a new material and efficient cause. Jesus Christ's body in the form of substance can be the latter but he barely can be the former because he is present in the host not physically or materially. It sounds confusing, unless we agree the that direct divine causation solves it in the purely divine manner.

However, on a broader scale the situation looks positively. Perhaps, Thomas Aquinas is uncritical in his theological presuppositions, but it is the other way around with the philosophical side of his work. He takes the Aristotelian vocabulary and conceptual world, critically and creatively reworks it and gives it a (partly) new meaning and a (partly) new significance. In other words, he detects a potential internal "translatability" (traduisibilite) [Dünne... 2013a: 1-2] in his material and makes an idiosyncratic "translation” (traduction) of it. Yet, these translational aspects are not external or purely linguistic - they are internal or conceptual as well.

Aquinas utilizes a creative hermeneutics and turns the more-or-less stable notions of peripatetic philosophy to flexible entities that can be stretched, bended and reformed, although their essence remains for the most part unchanged. He commits an act of conceptual transubstantiation over the notions such as "substance," "accidents," and "change." According to his interpretation, the substance acquires a new option or possibility of change and, in the specific case of the eucharist, becomes a connecting point between the transcendental and the human. It is through the substance of Jesus Christ's body that the Christians might touch the salvific (practical value) and otherworldly (contemplative value) reality. The accidents (or a thing's qualities) become bearers of the much more valuable content but remain absolutely real and sensible, becoming a surprisingly stable and strong link that connects two ends of an unusual type of change. The change (or conversion) itself acquires a new - the third possible - meaning that was in fact hypothetically hidden in the Aristotelian framework: now it can serve as a door to the miraculous and supernatural, which was a very crucial concept in the Middle Ages.

In brief, the reconceptualization that Aquinas did to these ideas and their theological background (the doctrine of the eucharist) results in the formation of a few untranslatable notions, which do not have much meaning outside the peculiarly Thomistic, or at least Christian-Latin vocabulary. But when they are looked at with full awareness of their context and author's intentions, they look not so much as contradictions, but rather as untranslatables. I would go even so far as to say that perhaps the creative touch that they received from the Dominican thinker from Aquino allows for further creative retranslations of these Thomistic untranslatables: Edward Schillebeeckx' "transsignification” [Schillebeeckx 1966] and more recent "personal realism” of Bernard Prusak [Prusak 2014: 249-258] might be good candidates. But an enquiry into the possible rendering(s) of St. Thomas transubstantiation in the $21^{\text {st }}$ century is a topic for another research. 


\section{СПИСОК ЛІТЕРАТУРИ / REFERENCES}

Bachmann-Medick, D. (Ed.). (2009). The Translational Turn (Vol. Special Issue). London: Routledge, \& Taylor \& Francis.

Bauerschmidt, F. C. (2005). Holy Teaching: Introducing the Summa Theologiae of St. Thomas Aquinas. Grand Rapids, MI: Brazos Press.

Cassin, B. (2004a). Esti, einai. In B. Cassin (Ed.), Vocabulaire européen des philosophies (pp. 418-429). Paris: Seuil/Le Robert.

Cassin, B. (2004b). Présentation. In Vocabulaire européen des philosophies (pp. XVII-XXII). Paris: Seuil/Le Robert.

Cassin, B. (2004c). Vocabulaire européen des philosophies. Dictionnaire des intraduisibles. Paris: Seuil/Le Robert.

Cassin, B. (2007). Intraduisible et mondialisation. Entretien réalisé par Michaël Oustinoff. Hermès, La Revue, 3(49), 197-204.

Cassin, B. (2014). Traduire les intraduisibles, un état des lieux. Cliniques Méditerranéennes, 2(90), 25-36.

Collins Latin Dictionary and Grammar. (1997). Glasgow: HarperCollins Publishers.

Collura, N. (2014). Some Reflections on the Eucharist as Fragment. Worship, 88(2), 151-170.

Courtine, J.-F. (2004). Essence, substance, subsistance, existence. In B. Cassin (Ed.), Vocabulaire européen des philosophies (pp. 400-414). Paris: Seuil/Le Robert.

Courtine, J.-F., \& Rijksbaron, A. (2004). To ti ên einai. In B. Cassin (Ed.), Vocabulaire européen des philosophies (pp. 1298-1304). Paris: Seuil/Le Robert.

Dünne, J., Schäfer, M. J., Suchet, M., \& Wilker, J. (2013a). Introdution : Phénomènes d'intraduisibilité et perturbations de processus des transmissions dans les langues, littératures, médias, cultures. In J. Dünne, M. J. Schäfer, M. Suchet, \& J. Wilker (Eds.), Les intraduisibles: langues, littératures, médias, cultures = Unübersetzbarkeiten: Sprachen, Literaturen, Medien, Kulturen (pp. 1-5). Paris: Éditions des archives contemporaines.

Dünne, J., Schäfer, M. J., Suchet, M., \& Wilker, J. (Eds.). (2013b). Les intraduisibles : langues, littératures, médias, cultures = Unübersetzbarkeiten : Sprachen, Literaturen, Medien, Kulturen. Paris: Éditions des archives contemporaines.

FitzPatrick, P. J., \& Baumann, P. (1995). Signs and Disguises: Sorting Out Transubstantiation. Commonweal, 122(2), 18-21.

Gutas, D. (2010). Origins in Baghdad. In R. Pasnau (Ed.), The Cambridge History of Medieval Philosophy (Vol. I, pp. 11-25). Cambridge: Cambridge UP.

Hägglund, B. (1968). History of Theology. (G. J. Lund, Trans.). Saint Louis, MO: Concordia Publishing House.

Kerr, F. (2009). Thomas Aquinas: A Very Short Introduction. Oxford: Oxford UP.

Leone, M., \& Parmentier, R. J. (2014). Representing Transcendence: The Semiosis of Real Presence. Signs and Society, 2(S1), S1-S23. http://doi.org/10.1086/674529

Marenbon, J. (2007). Medieval Philosophy: An Historical and Philosophical Introduction. London: Routledge.

Mavroudi, M. (2015). Translations from Greek into Latin and Arabic during the Middle Ages: Searching for the Classical Tradition. Speculum, 90(1), 28-59. http://doi.org/10.1017/S0038713414002450

McCord Adams, M. (2010). Some Later Medieval Theories of the Eucharist: Thomas Aquinas, Giles of Rome, Duns Scotus, and William Ockham. Oxford: Oxford UP.

Muller, R. A. (1985). Dictionary of Latin and Greek Theological Terms: Drawn Principally from Protestant Scholastic Theology. Grand Rapids, MI: Baker Books.

Nichols, T. L. (2005). "This Is My Body": How to Understand Transubstantiation. Commonweal, 132(17), 12-14.

Oxford Latin Dictionary. (1968). Oxford: Oxford UP.

Padgett, A. (2000). Aristotelianism. In T. A. Hart (Ed.), Dictionary of Historical Theology (pp. 31-32). Grand Rapids, MI: William B. Eerdmans Publishing Company.

Prusak, B. P. (2014). Explaining Eucharistic "Real Presence”: Moving Beyond a Medieval Conundrum. Theological Studies, 75(2), 231-259. http://doi.org/10.1177/0040563914530613

Schillebeeckx, E. (1966). Transubstantiation, Transfinalization, Transfiguration. Worship, 40(6), 324-338. 
Thomas Aquinas. (1965). The Eucharistic Presence (3a. 73-78). (W. Barden, Ed. \& Trans.). (Vol. 58). London: Eyre and Spottiswoode.

Vollert, C. (2002). Transubstantiation. In T. Carson \& J. Cerrito (Eds.), New Catholic Encyclopedia (2nd ed., Vol. 14, "Thi-Zwi”, pp. 158-160). Washington, DC: The Catholic University of America Press.

Vos, A. (2009). Solus Christus. The Inaugural Lecture at the Doctoral Colloquium, August 31, 2009. Leuven: Evangelishe Theologische Faculteit.

Vos, A. (2010). Scotus' Significance for Western Philosophy and Theology. Porto: Fédération Internationale des Instituts d'Études Médiévales.

Walsh, L. G. (2005). Sacraments. In R. van Nieuwenhove, \& J. Wawrykov (Eds.), The Theology of Thomas Aquinas (pp. 326-364). South Bend, IN: University of Notre Dame Press.

Одержано / Received 11.11.2015

\section{Rostislav Tkachenko}

\section{A Thomistic Untraslatable: a Conceptual Analysis of Aquinas' Doctrine of Transubstantiation}

The article treats the doctrine of transubstantiation or the Eucharistic change as formulated by Thomas Aquinas in his Summa theologiae, Question 75, against its double conceptual (Christian religious vs. Aristotelian philosophical), as well as double linguistic (Latin vs. translated Greek), background. The doctrine is presented and analyzed as a philosophicaltheological theory that can be explicated and assessed using the concept of philosophical untranslatable(s), recently discovered and brought to the fore by the proponents of the "translational turn” in continental philosophy. It is argued on the basis of careful study of Aquinas' text that the notion of transubstantiation should be identified as a conceptual untranslatable.

Here the term "untranslatable" means a unique reinterpretation of Aristotelian language of being and change, which results in a conceptual innovation that has some inherent problems as well as creative and promising inventions. The usage of such a concept is justified by the fact that the reconceptualization that Aquinas did to a number of Peripatetic ideas creates a few untranslatable notions, which do not have much meaning outside the peculiarly Thomistic Latin vocabulary. Despite some criticisms they are not necessarily to be regarded as contradictions, but rather as thomistic untranslatables.

Rostislav Tkachenko, ThM, PhD candidate at Evangelische Theologische Faculteit, Leuven; Assistant Professor of Historical Theology at Odessa Theological Seminary of Evangelical Christians-Baptists, Adjunct Professor of Historical Theology at Lviv Theological Seminary.

Ростислав Ткаченко, магістр богослов'я і релігієзнавства, аспірант у Протестантському (Свангелічному) Богословському університеті, м. Льовен (Бельгія); викладач історичного богослов'я в Одеській богословській семінаріі СХБ, позаштатний викладач історичного богослов'я у Львівській богословській семінарії ХВС.

Ростислав Ткаченко, магистр богословия и религиоведения, аспирант богословия в Протестантском (Евангелическом) Богословском университете, г. Лёвен (Бельгия); преподаватель исторического богословия в Одесской богословской семинарии ЕХБ, внештатный преподаватель исторического богословия в Львовской богословской семинарии ХВЕ.

e-mail: rostislavtkachenko@gmail.com 